\title{
Analysis of Essential and Toxic Elements in Jujube Fruits Collected from Different Locations in China
}

\author{
Qinghua Yan ${ }^{1 *}$, Yongtao Liu ${ }^{1}$ and Li Yang ${ }^{2}$ \\ ${ }^{1}$ Department of Life Science and Technology, Xinxiang Medical University, Xinxiang Henan 453003, ${ }^{2}$ Department of \\ Experimental Center, Henan Institute of Science and Technology, Xinxiang Henan 453003, PR China \\ *For correspondence: Email: yqh3499@aliyun.com; Tel: +86-373-3831928
}

\begin{abstract}
Purpose: To develop a simple and precise method for the determination of the levels of both essential and toxic elements in jujube collected from different locations in China.

Methods: Dried jujube fruits collected were digested by optimized microwave procedure. Inductively coupled plasma atomic emission spectrometry was employed to evaluate essential elements, viz, calcium, magnesium, manganese, iron and copper ( $\mathrm{Ca}, \mathrm{Mg}, \mathrm{Mn}$, $\mathrm{Fe}$ and $\mathrm{Cu}$ ) and toxic elements, namely, aluminum, lead and cadmium $(A l, P b$ and $C d$ ) in four jujube fruits.

Results: The results show that the jujube fruits were rich in essential elements and had low contents of toxic elements. The levels of the elements varied significantly amongst the four jujube fruits $(p<0.05)$. Method validation indicates that the proposed method was accurate and precision. The detection limits were $0.0005-0.0100 \mu \mathrm{g} / \mathrm{mL}$ while recovery ranged from $91.6-105.0 \%$, with relative standard deviation $(R S D)<5 \%$.

Conclusion: Five essential elements and two toxic elements (except cadmium) varied widely in their contents in the four jujube fruits. Knowledge of the contents of these elements would provide consumers with information on the quality of jujube fruits.
\end{abstract}

Keywords: Jujube fruits, Essential and toxic elements, Microware digestion, Inductively coupled plasma atomic emission spectrometry

Tropical Journal of Pharmaceutical Research is indexed by Science Citation Index (SciSearch), Scopus, International Pharmaceutical Abstract, Chemical Abstracts, Embase, Index Copernicus, EBSCO, African Index Medicus, JournalSeek, Journal Citation Reports/Science Edition, Directory of Open Access Journals (DOAJ), African Journal Online, Bioline International, Open-J-Gate and Pharmacy Abstracts

\section{INTRODUCTION}

Jujube fruit is a multipurpose tropical fruit tree grown primarily for its delicious fruit, and has been used for human consumption and medicinal purposes for more than 4000 years [1]. Jujube fruit is one of the superior herbal medicines, it nourishes the blood, improves quality of sleep and regulates digestive system [2]. Today, the fruit of jujube is considered as food supplement, it contains a variety of nutrients, including carbohydrates, minerals, vitamins, sugars, and amino acids [3]. Being a herbal medicine or health food supplement, the pharmacological results indicate that the fruit exhibits antioxidant activities [4], immunological activities [5], potential sedative effects [6] treatment of jaundice in neonates [7], and anti-inflammatory effects [8].

In the long process of plant growth, due to the impact of water, soil transformation and the atmosphere, the plants absorb all kinds of elements in the environment. Jujube fruit, in addition to its content of a large number of elements beneficial to human body, also contains harmful heavy metal elements. 
This article intends to provide information about some contents of essential and toxic elements in some jujube fruit types from different locations in China.

\section{EXPERIMENTAL}

\section{Materials}

Inductively coupled plasma atomic emission spectrometry standard stock solutions of $\mathrm{Ca}, \mathrm{Mg}$, $\mathrm{Mn}, \mathrm{Fe}, \mathrm{Cu}, \mathrm{Al}, \mathrm{Pb}$ and $\mathrm{Cd}$ at a concentration of $1000 \mu \mathrm{g} / \mathrm{mL}$ in dilute nitric acid were obtained from Merck (Darmstadt, Germany), and working solutions were prepared by diluting the stock solutions with $2 \%(\mathrm{v} / \mathrm{v}) \mathrm{HNO}_{3}$ immediately before use. Purified water obtained from an SG ultra clear UV plus system $(18.2 \mathrm{M} \Omega / \mathrm{cm}$, Wasseraufbereitung und Regenerierstation $\mathrm{GmbH}$, Germany) was used for standard dilutions and other necessary preparations. All chemicals and reagents employed were of analytical grade.

\section{Instrumentation}

A Perkin Elmer model Optima 2100DV ICP-AES (Norwalk, CT, USA) was used for determination of selected elements in jujube fruits. The operation conditions were as follows: RF Power: 1.3kw; Auxiliary gas flow rate (Ar): $0.2 \mathrm{~L} / \mathrm{min}$; Cooling gas flow (Ar): $15.0 \mathrm{~L} / \mathrm{min}$; Carrier gas flow (Ar): $0.65 \mathrm{~L} / \mathrm{min}$. These conditions were established after optimization of the instrumental parameters.

A microwave sample preparation system of CEM Model MARS 5 (CEM Corp., Matthews, USA) was used in the study. The optimization microwave digestion conditions were as follows: Stage 1, power: $800 \mathrm{~W}$; time taken to raise the temperature to $120^{\circ} \mathrm{C}$ : $5 \mathrm{~min}$; Stage 2, power: $800 \mathrm{~W}$, temperature rise time: 4 min, running temperature: $140^{\circ} \mathrm{C}$, running time: $4 \mathrm{~min}$; Stage 3, power: $800 \mathrm{~W}$, temperature rise time: $4 \mathrm{~min}$, running temperature: $160^{\circ} \mathrm{C}$, running time: 10 $\min$.

\section{Sample preparation}

Four commercial dried jujube fruits (Xinjiang hetian jujube, Hebei jujube, Xinzheng jujube, Huixian jujube) were collected from different locations (Xinjiang hetian, Hebei, Xinzheng, Huixian jujube) in China. All samples were washed with deionized water before use for the experiments. Jujube seed were removed after natural drying. The jujube fruits were baked in oven at $50^{\circ} \mathrm{C}$ for $8 \mathrm{~h}$. All samples were smashed using high speed universal grinder.
For each sample, six replicate powder samples $(0.5 \mathrm{~g})$ of the same jujube fruits were accurately weighed into the different digestion vessels, 12 $\mathrm{mL}$ concentrated $\mathrm{HNO}_{3}$ and $2 \mathrm{~mL} \mathrm{H}_{2} \mathrm{O}_{2}$ were added. The samples were digested according to the microwave digestion procedures optimized. In order to reduce the acid concentration of digestion solution, the digestion solution was transferred into the different beakers and the beakers were put on a heating plate at $150^{\circ} \mathrm{C}$ for 3 h. After cooling to room temperature, the solutions were filtered into $25 \mathrm{~mL}$ volumetric flask and made up to volume with $2 \% \mathrm{HNO}_{3}$. The solutions were subsequently analyzed for selected essential and toxic elements using inductively coupled plasma atomic emission spectrometry.

\section{Method validation}

For essential and toxic elements, regression equation was performed using mixed standard solutions of $0.00,0.5,1.00,2.00,4.00$ and 8.00 $\mu \mathrm{g} / \mathrm{mL}$ (Ca, Mg, Mn, Fe, $\mathrm{Cu}, \mathrm{Al}, \mathrm{Pb}$ and $\mathrm{Cd}$ ) prepared by serial dilution of ICP-AES multielement standard stock solution IV of 1000 $\mu \mathrm{g} / \mathrm{mL}$ of 23 elements (Merck, Germany) with $2 \%$ $\mathrm{HNO}_{3}$.

To evaluate the analytical characteristics of the method for each element, the detection limits were calculated. The LOD was calculated using $3 \mathrm{SD} / \mathrm{b}$ (SD is the standard deviation of the curve and $b$ is the slope of the curve).

The precision of the method was evaluated by the relative standard deviation (RSD) in six replicate determinations on a randomly chosen Xinjiang hetian jujube sample, The equation of the relative standard deviation was calculated using $S / \bar{x}$ ( $S$ is the standard deviation and $\bar{x}$ is equal to the mean).

Recovery was carried out on Xinjiang hetian jujube to demonstrate good recovery. The accuracy of the method was determined by spiking with the mixed standard solution at different concentration levels for each element in Xinjiang hetian jujube. Triplicate experiments were performed. The ratios of measured and added amounts were calculated to obtain recovery.

\section{Statistical analysis}

The data were analysed using SPSS software (version 13.0, SPSS) and mean results were based on at least six replicates. In order to verify differences of the same essential and toxic elements content in the different jujube fruits 
studied, one factor analysis of variance was applied with the level of significance set at $p<$ 0.05 .

\section{RESULTS}

Analytical wavelength $(\mathrm{nm})$, detection limits $(\mu \mathrm{g} / \mathrm{mL})$ and regression data

The analytical wavelength $(\mathrm{nm})$, detection limits $(\mu \mathrm{g} / \mathrm{mL})$, regression equation and correlation coefficient are presented in Table 1 . The results indicate that linearity for all trace elements was good, with correlation coefficient $\geq 0.9998$. Detection limits ranged from 0.0005 to 0.0100 $\mu \mathrm{g} / \mathrm{mL}$.

\section{Precision of the method}

In order to verify the accuracy and precision of the method, Xinjiang hetian jujube sample was randomly chosen to evaluate the precision of method $(n=6)$ and the results were given in Table 2 . The results indicate good precision under the analytical conditions used since the relative standard deviations were $<5 \%$ and the method was precision.

\section{Recovery of developed method}

A recovery work was carried out to demonstrate the validity of the method. Xinjiang hetian jujube was selected to detect the recovery through quantity added. Xinjiang hetian jujube samples were prepared and determined using the recommended procedure. From Table 3 the results were considered satisfactory because recovery ranged from 91.6 to $105.0 \%$.

Table 3: Recovery of developed method $(\mu \mathrm{g} / \mathrm{mL})$

\begin{tabular}{lllll}
\hline Element & $\begin{array}{l}\text { Base } \\
\text { value }\end{array}$ & $\begin{array}{l}\text { Quantity } \\
\text { added }\end{array}$ & $\begin{array}{l}\text { Quantity } \\
\text { found }\end{array}$ & $\begin{array}{l}\text { Recovery } \\
(\%)\end{array}$ \\
\hline $\mathrm{Ca}$ & $838.2 \pm 21.2$ & 200 & $1021.3 \pm 20.1$ & 91.6 \\
$\mathrm{Mg}$ & $423.3 \pm 17.1$ & 200 & $609.7 \pm 10.0$ & 93.2 \\
$\mathrm{Mn}$ & $4.5 \pm 0.3$ & 5 & $9.4 \pm 0.3$ & 98.0 \\
$\mathrm{Fe}$ & $138.4 \pm 8.3$ & 100 & $240.0 \pm 1.6$ & 101.6 \\
$\mathrm{Cu}$ & $13.8 \pm 1.5$ & 10 & $24.3 \pm 0.56$ & 105.0 \\
$\mathrm{Al}$ & $32.0 \pm 1.3$ & 10 & $42.4 \pm 1.0$ & 104.0 \\
$\mathrm{~Pb}$ & $3.1 \pm 0.2$ & 5 & $7.7 \pm 0.3$ & 92.0 \\
$\mathrm{Cd}$ & $\mathrm{ND}$ & 1 & $0.97 \pm 0.10$ & 97.0 \\
\hline
\end{tabular}

\section{Contents of essential and toxic elements}

The contents of essential and toxic elements in the jujube products that were determined in this study are summarized in Table 4. All jujubes had high essential element concentrations of $\mathrm{Ca}, \mathrm{Mg}$ and $\mathrm{Fe}$. The content of $\mathrm{Cu}$ was lower. The contents of essential had significance differences among four different jujube samples $(p<0.05)$. Ca (1297.3 $\mu \mathrm{g} / \mathrm{g}), \mathrm{Mg}(668.1 \mu \mathrm{g} / \mathrm{g}), \mathrm{Mn}(6.1 \mu \mathrm{g} / \mathrm{g})$ and $\mathrm{Cu}(73.6 \mu \mathrm{g} / \mathrm{g})$ had the highest concentration in Xinzheng jujube. Fe $(138.4 \mu \mathrm{g} / \mathrm{g})$ was highest concentration in Xinjiang hetian jujube. The concentration of $\mathrm{Mn}$ was the lowest in all the samples.

Table 1: Analytical wavelength $(\mathrm{nm})$, detection limits $(\mu \mathrm{g} / \mathrm{mL})$, regression equation and correlation coefficient for the elements

\begin{tabular}{|c|c|c|c|c|}
\hline Element & $\begin{array}{c}\text { Analytical } \\
\text { wavelength (nm) }\end{array}$ & $\begin{array}{l}\text { Detection limits } \\
(\mu \mathrm{g} / \mathrm{mL})^{\mathrm{a}}\end{array}$ & Regression equation $^{b}$ & Correlation coefficient (r) \\
\hline $\mathrm{Ca}$ & 317.933 & 0.0062 & $Y=93930 X+916.3$ & 0.999997 \\
\hline $\mathrm{Mg}$ & 279.077 & 0.0028 & $Y=11520 X+731.9$ & 0.999892 \\
\hline $\mathrm{Mn}$ & 257.610 & 0.0005 & $Y=838200 X+19070.8$ & 0.999986 \\
\hline $\mathrm{Fe}$ & 259.939 & 0.0023 & $Y=134700 X+662.9$ & 0.999999 \\
\hline $\mathrm{Cu}$ & 324.752 & 0.0100 & $Y=234600 X+10609.5$ & 0.999945 \\
\hline $\mathrm{Al}$ & 396.153 & 0.0041 & $Y=123800 X+1972.9$ & 0.999993 \\
\hline $\mathrm{Pb}$ & 220.353 & 0.0043 & $Y=6073 X+479.1$ & 0.999834 \\
\hline $\mathrm{Cd}$ & 228.802 & 0.0032 & $Y=24862 X+229.8$ & 0.999998 \\
\hline
\end{tabular}

${ }^{a}$ Calculated according to 3 times the $S D$ of the blank $(n=10) ;{ }^{b} Y=$ sensitivity $(c p s), X=$ concentration of compound $(\mu \mathrm{g} / \mathrm{mL})$

Table 2: Results of precision test $(\mu \mathrm{g} / \mathrm{mL})$

\begin{tabular}{ccccccccc}
\hline Element & $\mathbf{1}$ & $\mathbf{2}$ & $\mathbf{3}$ & $\mathbf{4}$ & $\mathbf{5}$ & $\mathbf{6}$ & $\begin{array}{c}\text { Mean } \\
\text { value }\end{array}$ & $\begin{array}{c}\text { Precision } \\
\text { (\%RSD) }\end{array}$ \\
\hline $\mathrm{Ca}$ & 861.3 & 838.2 & 846.9 & 819.8 & 836.6 & 849.7 & 838.2 & 1.40 \\
$\mathrm{Mg}$ & 411.5 & 440.1 & 422.8 & 407.6 & 432 & 425.1 & 423.3 & 2.89 \\
$\mathrm{Mn}$ & 4.6 & 4.5 & 4.5 & 4.5 & 4.5 & 4.4 & 4.5 & 1.41 \\
$\mathrm{Fe}$ & 149.2 & 130.2 & 138.9 & 141.6 & 132.9 & 137.8 & 138.4 & 4.85 \\
$\mathrm{Cu}$ & 13.6 & 13.7 & 13.8 & 13.9 & 13.9 & 14 & 13.8 & 1.07 \\
$\mathrm{Al}$ & 30.2 & 32.9 & 32.7 & 31.6 & 32 & 30.9 & 32 & 2.50 \\
$\mathrm{~Pb}$ & 3 & 3.2 & 3.2 & 3.1 & 3 & 3.1 & 3.1 & 2.89 \\
$\mathrm{Cd}$ & $\mathrm{ND}$ & $\mathrm{ND}$ & $\mathrm{ND}$ & $\mathrm{ND}$ & $\mathrm{ND}$ & $\mathrm{ND}$ & $\mathrm{ND}$ & ND \\
\hline
\end{tabular}


Table 4: Contents of essential and toxic trace elements in jujube fruits $(\mu \mathrm{g} / \mathrm{g})$

\begin{tabular}{cccccc}
\hline Element & & $\begin{array}{c}\text { Xinjiang hetian } \\
\text { jujube }\end{array}$ & Hebei jujube & Xinzheng jujube & Huixian jujube \\
& $\mathrm{Ca}^{*}$ & $838.2 \pm 21.2$ & $560.6 \pm 10.0$ & $1297.3 \pm 48.9$ & $608.8 \pm 9.7$ \\
& $\mathrm{Mg}^{*}$ & $423.3 \pm 17.1$ & $330.4 \pm 4.5$ & $668.1 \pm 30.8$ & $324.4 \pm 20.2$ \\
Essential elements & $\mathrm{Mn}^{*}$ & $4.5 \pm 0.3$ & $2.5 \pm 0.1$ & $6.1 \pm 0.3$ & $2.2 \pm 0.1$ \\
& $\mathrm{Fe}^{*}$ & $138.4 \pm 8.3$ & $112.8 \pm 9.6$ & $72.3 \pm 3.0$ & $49.1 \pm 3.8$ \\
& $\mathrm{Cu}^{*}$ & $13.8 \pm 1.5$ & $4.8 \pm 0.2$ & $73.6 \pm 3.2$ & $4.1 \pm 0.1$ \\
\hline \multirow{2}{*}{ Toxic elements } & $\mathrm{Al}^{*}$ & $32.0 \pm 1.3$ & $4.8 \pm 0.2$ & $50.6 \pm 2.4$ & $15.9 \pm 0.6$ \\
& $\mathrm{~Pb}^{*}$ & $3.1 \pm 0.2$ & $3.0 \pm 0.2$ & $4.2 \pm 0.5$ & $3.6 \pm 0.3$ \\
& $\mathrm{Cd}$ & $\mathrm{ND}$ & $\mathrm{ND}$ & $\mathrm{ND}$ & $\mathrm{ND}$ \\
\hline ND $=$ Not detected; * & \multicolumn{4}{c}{}
\end{tabular}

The contents of toxic had also significance differences among four different jujube samples $(p<0.05)$. Al was relatively higher than the other two toxic elements. Content of $\mathrm{Pb}$ was low (ranged from 3.0 to $4.2 \mu \mathrm{g} / \mathrm{g}$ ). The concentrations of some toxic heavy metal such as $\mathrm{Cd}$ in jujube fruits were too low to be detected using the available analytical technique.

\section{DISCUSSION}

Calcium is an essential trace element of human body, it not only composite the body structure, but only regulate the body. It is the origin of human life and it is the most abundant inorganic elements in human body, In the human body calcium (99\%) deposit in bones and teeth, and promotes their growth and development, maintain their morphology and hardness. Calcium (1\%) in the blood and soft tissue cells help regulate physiological function. The $\mathrm{Ca}$ levels in analysed samples were high. According to the Food and Nutrition Board [9], the recommended daily intake of $\mathrm{Ca}$ is $1000 \mathrm{mg} /$ day. Thus, the jujube is a rich source of dietary $\mathrm{Ca}$.

Magnesium plays an important role in human body. It is the activator of many enzymes. Magnesium has a sedative effect and strengthens the elderly neural, inhibition function of the nervous system. Magnesium deficiency can lead to metabolic disorder of striated muscle. In our work, Mg level was the highest in Xinzheng jujube.

Manganese acts as a catalyst and cofactor in many enzymatic processes involved in the synthesis of fatty acids and cholesterol [10]. At the same time, the element plays an important role in the synthesis of mucopolysaccharide required for skeletal and cartilage structural matrix and thus is important in skeletal and connective tissue development. Apart from these, other health benefits of $\mathrm{Mn}$ include active involvement in absorption of calcium, proper functioning of thyroid, sex hormones and in regulating blood sugar level [11]. Mn permissible limit in medicinal plants set by FAONHO (1984) was $2 \mu \mathrm{g} / \mathrm{g}$ [12]., while its content in Xinzheng jujube was $6.1 \mu \mathrm{g} / \mathrm{g}$ that is about three times higher, which showed Xinzheng jujube has high tendency to accumulate $\mathrm{Mn}$.

Iron is one of the main raw materials for synthesis of hemoglobin in human body. It is the body of oxidation-reduction reactions in enzymes and electron transfer of the carrier, but also an important part of catalase and cytochrome. Iron deficiency can make the content of hemoglobin and the activity of physiological decrease and cause oxygen significantly to reduce, thus affecting the supply of the nutrient and oxygen in the brain. Fe $(138.4 \mu \mathrm{g} / \mathrm{g})$ had the highest concentration in Xinjiang hetian jujube. But the content of $\mathrm{Fe}$ in Huixian jujube was the lowest.

Copper is the catalyst in carbohydrate metabolism, its main function is to assist the hematopoietic, namely the catalytic synthesis of hemoglobin. Therefore, copper deficiency will make the activity of important enzyme reduce in vivo, and can lead to bone disorder. The content of $\mathrm{Cu}$ was high in Xinzheng and Xinjiang hetian jujube. So, the jujube products are recommended as a source of dietary $\mathrm{Cu}$, too.

The ecological importance of heavy metals has attracted a great deal of attention from governmental and regulatory bodies who are concerned in reducing the human health risk associated to the environmental pollution [13]. The toxicity of various heavy metal elements has been well-known and documented for many years. As early as the second century $\mathrm{BC}$ it was apparent that exposure to lead $(\mathrm{Pb})$ could be detrimental [14], $\mathrm{Cd}$ and $\mathrm{Pb}$ are very harmful elements to the human body. Contaminated sediments are one of the several means through which soils are enriched with heavy metals. Al is a low toxicity metal. Food containing aluminum 
exceed national standards can cause a harm to human body. The levels of $\mathrm{Al}, \mathrm{Pb}$ and $\mathrm{Cd}$ in the analyzed samples did not appear to reach pollution levels [15]. Many factors may contribute to the accumulation of metals in jujube fruits. These include organic matter contents of soil, environmental pollutions from manufacturing process, etc.

\section{CONCLUSION}

The microwave assisted extraction applied in this study is a reproducible, convenient and rapid sample preparation method for the direct determination of trace elements in jujube products by inductively coupled plasma atomic emission spectrometry. The developed method shows good precision and accuracy. The jujube fruits examined are rich in essential trace elements and low in toxic trace elements.

\section{ACKNOWLEDGEMENT}

The authors would like to thank Scientific Research Fund of Xinxiang Medical University (Grant no. 2013QN108) and the National Natural Science Foundation of China (Grant No. 51304064) for financially supporting this research.

\section{REFERENCES}

1. Lee $R$, Uncommon fruits worthy of attention. Reading, MA: Addison-Wesley. 1991; pp 139-146.

2. Chen JP, Li ZG, Maitinuer M, Wendy $L Z$, Janis $Y X Z$, Candy $T W L$, Kevin Y Z, Ping Y, Roy CYC, David TWL, Tina TXD, Karl WKT. Chemical and Biological Assessment of Ziziphus jujuba Fruits from China: Different Geographical Sources and Developmental Stages. J Agric Food Chem 2013; 61: 7315-7324.

3. U.S. Department of agriculture, agricultural research service. USDA National nutrient database for standard reference: release 25. 2012.

4. Choi SH, Ahn JB, Kozukue N, Levin CE, Friedman M. Distribution of free amino acids, flavonoids, total phenolics, and antioxidative activities of jujube (Ziziphus jujuba) fruits and seeds harvested from plants grown in Korea. J Agric Food Chem 2011; 59: 6594-6604.

5. Li JW, Shan L, Liu YF, Fan LP, Ai LZ. Screening of a functional polysaccharide from Zizyphus jujuba $\mathrm{cV}$. jinsixiaozao and its property. Int $\mathrm{J}$ Biol Macromol 2011b; 49: 255-259.

6. Cao JX, Zhang QY, Cui SY, Cui $X Y$, Zhang JA, Zhang YH, Bai YJ, Zhao YY. Hypnotic effect of jujubosides from Semen Ziziphi Spinosae. J Ethnopharmacol 2010; 130: 163-166.

7. Ebrahimi S, Ashkani-Esfahani S, Poormahmudi A. Investigating the efficacy of Zizyphus jujuba on neonatal jaundice. Iran J Pediatr 2011; 21: 320-324.

8. Goyal R, Sharma PL, Singh M. Possible attenuation of nitric oxide expression in anti-inflammatory effect of Ziziphus jujuba in rat. J Nat Med 2011; 65: 514-518.

9. Institute of Medicine. Dietary reference intakes for vitamin A, vitamin K, Boron, Chromium, Copper, Iodine, Iron, Manganese, Molybdenum, Nickel, Silicon, Vanadium, and Zinc. Washington D.C: National Academy Press 2001; 290-442.

10. Shirin K, Imad S, Shafiq S, Fatima K. Determination of major and trace elements in the indigenous medicinal plant Withania somnifera and their possible correlation with therapeutic activity. J Saudi Chem Soc 2010; 14: 97-100.

11. Mutaftchiev K, Tzachev K, Alexiev A. Spectrophotometric catalytic method for determination of manganese (II) in human blood serum. Bull Chem Technol Macedonia 1999; 18: 37-40.

12. Ismat $F$, Shahida W, Jamshed Hussain Z. Essential and toxic elements in three Pakistan's medicinal fruits (Punica granatum, Ziziphus jujuba and Piper cubeba) analysed by INAA. Int J Food Sci Nutr 2012; 63: 310317.

13. Orton-Bermea O, Hernández-Álvarez E, González Hernández G, Romero F, Lozano R, BeramendiOrosco LE. Assesment of heavy metal pollution in urban topsoils from the metropolitan area of Mexico City. J Geochem Explor 2008; 98: 43-56.

14. Pearce JMS. Burton's line in lead poisoning. Eur Neurol 2007; 57: 118-119.

15. Ministry of Health. PRC and National Committee of Standardization, the Maximum Levels of Contaminants in Foods (GB2762-2005). Beijing: Standards Press of China, 2005. 